Qin Xin ORCID iD: 0000-0002-6790-355X

Heather Dettman ORCID iD: 0000-0001-6582-3604

20-00461

Environmental Toxicology

L. Lara-Jacobo et al.

Fish embryotoxicity of weathering crude oil

\title{
Fate and Fathead Minnow Embryotoxicity of Weathering Crude Oil in a Pilot-Scale Spill Tank
}

\author{
Lara-Jacobo $\mathrm{LR}^{1}$, Gauthier $\mathrm{C}^{1}$, Xin $\mathrm{Q}^{2}$, Dupont $\mathrm{F}^{3}$, Couture $\mathrm{P}^{1}$, Triffault-Bouchet $\mathrm{G}^{3}$, \\ Dettman $\mathrm{HD}^{2}$ and Langlois $\mathrm{VS}^{1^{*}}$ \\ ${ }^{1}$ Institut national de la recherche scientifique (INRS), Centre Eau Terre \\ Environnement, 490 rue de la Couronne, Quebec, QC, G1K 9A9; \\ ${ }^{2}$ Natural Resources Canada (NRCan), CanmetENERGY, 1 Oil Patch Drive, Devon, \\ AB, T9G 1A8; \\ ${ }^{3}$ Ministère de l'Environnement et de la Lutte contre les changements climatiques, \\ Centre d'expertise en analyse environnementale du Québec, Quebec, QC, G1P 3W8.
}

This article has been accepted for publication and undergone full peer review but has not been through the copyediting, typesetting, pagination and proofreading process, which may lead to differences between this version and the Version of Record. Please cite this article as doi: 10.1002/etc.4891.

This article is protected by copyright. All rights reserved. 
(Submitted 23 June 2020; Returned for Revisions 20 July 2020; Accepted 01 October 2020)

\begin{abstract}
For several years now, the Natural Resources Canada (NRCan) research facility at CanmetENERGY Devon has been performing experiments in a pilot-scale spill tank using 1,200 $\mathrm{L}$ of river water to examine the physical and chemical behaviours of various crude oil/water mixtures under varying water temperature regimes. As oil toxicity can be modulated by weathering of the petroleum products, this study aimed to assess changes in fish embryotoxicity to mixed sweet blend (MSW) crude oil as it weathered at air and water temperatures of $14^{\circ} \mathrm{C}$ and $15^{\circ} \mathrm{C}$ respectively for 28 days. The physicochemical behaviour of the oil was also monitored. Water samples were taken from the spill tank five times during the 28-day experiment at days $1,6,14,21$, and 28 and were used to perform toxicity exposures using fathead minnow embryos (Pimephales promelas). For each water sampling day, newly fertilized embryos were exposed to a serial dilution of the spill tank water, noncontaminated river water (used in the spill tank), and a reconstituted water laboratory control. Embryos were raised until hatching. While mortality was not significantly altered by the oil contamination over the time period, malformation occurrence and severity showed concentration-dependent responses to all contaminated water collected. Data suggest that days 14, 21, and 28 were the most toxic time periods for the fish embryos, which corresponded to increasing concentrations of unidentified oxidized organic compounds detected by Q-TOF. This study highlights a novel area for oil research, which could help to better understand the toxicity associated with oil weathering for aquatic species.
\end{abstract}

This article is protected by copyright. All rights reserved. 
Keywords: Fish; Sweet crude oil; Gene expression; Malformations; Pimephales promelas; fathead minnow.

This article includes online-only Supplemental Data.

*Address correspondence to valerie.langlois@inrs.ca.

Published online XXXX 2020 in Wiley Online Library (www.wileyonlinelibrary.com).

DOI: 10.1002/etc.xxxx

\section{Introduction}

The chemical complexity of crude oil increases the difficulty of environmental risk assessments for ecosystems that may be exposed to an oil spill (Wang et al. 2006). One of the major crude oil disasters in subarctic environments occurred on March $24^{\text {th }}$, 1989 when the Exxon Valdez spilled 35,000 metric tonnes of crude oil in the waters of Prince William Sound, Alaska, USA (Brown et al. 1996). Until this event, there were few studies related to the toxicity of petroleum products to fish embryos. Currently, the literature on fish toxicity to crude oils has increased and we now better understand the correlation between the observed toxicity to fish embryos with the amount of dissolved and bioavailable oil (Beyer et al. 2016). Pericardial and yolk sac edemas, spinal and craniofacial deformities, and cardiac or circulatory failure are among the most frequent embryotoxicity responses observed following crude oil exposure (Jung et al. 2011). It is now well known that the complex crude oil mixture does weather with time, which changes its chemical profile (Adams et al. 2014; Bornstein et al. 2014; Carls et al. 1999; Heintz et al. 1999) and so could modulate its toxicity.

This article is protected by copyright. All rights reserved. 
Crude oil is made up of a wide range of organic compounds, from very volatile hydrocarbons, such as propane, butane, and benzene to larger, more complex compounds such as asphaltenes, resins, and waxes (Wang et al. 2003). Once oil is spilled in a water environment, it is immediately subject to a variety of abiotic and biotic processes, including spreading, drifting, dispersion, stranding, evaporation, dissolution, biodegradation, photo-oxidation, and emulsification (Dew et al. 2015). Waves provide mixing energy that can break surface films of oil and distribute oil droplets into the water column (Lee et al. 2015). Polar compounds in the oil have relatively high-water solubility and so, with time, leave the oil phase and dissolve into the water (Wallace et al. 2020). Given that the dissolved fraction of oil can diffuse across biological membranes (e.g., gills), solubility is arguably the most important factor in determining toxicity to aquatic biota (Cherr et al. 2017). Differences in oil composition due to the origin of different crudes can cause significant differences in the fate and behavior of those oils in water (Dew et al. 2015). Overall, light aromatics in crude oil, such as benzene/toluene/ethylbenzene/xylene (BTEX), have acute toxicity to organisms, but tend to evaporate or biodegrade rapidly. Intermediate-sized components, such as polycyclic aromatic hydrocarbons (PAHs) and alkylated PAHs, are less volatile and contribute less to acute toxicity because they are taken up more slowly than lower molecular weight compounds (Dupuis \& Ucán-Marín, 2015). However, PAHs and alkylated PAHs are responsible for more chronic, mutagenic and carcinogenic impacts to a higher extent than $n$-alkanes and other petroleum biomarkers (Meador \& Nahrgang, 2019; Wallace et al. 2020). It is also clear that 2-to-3-ringed PAHs have higher bioavailability than those with more rings (4-to-5) (Wu et al. 2012). This is consistent with PAHs that have higher octanol-water partition coefficient $\left(\mathrm{K}_{\mathrm{ow}}\right)$

This article is protected by copyright. All rights reserved. 
values being less polar and, so less water-soluble (Lee et al., 2015). Strong adsorption of PAHs to sediment particles may also lead to their low bioavailability and biodegradation rate, preserving them in sediment for an extended period (Wang et al., 2004). The very heavy components, such as asphaltenes and resins, are thought not to be toxic because they do not readily cross biological membranes in the environment. However, they are the most persistent oil compounds due to their extremely low solubility in water (Lee et al., 2015).

Several studies have assessed the impact of crude oil on fish. Adams and colleagues (2013) exposed Atlantic herring (Clupea harengus) to artificially weathered Middle America (MESA) crude oil using laboratory-prepared water accommodated fractions (WAFs) and chemically enhanced WAF (CEWAF) daily. Malformations, developmental delays, pericardial edema, decreased heart rate, and blue sac disease were observed. Nakayama et al. (2008) exposed Japanese flounder (Paralichthys olivaceus) to unweathered Bunker C heavy fuel oil to study the immunotoxic effects of heavy oil and the biological responses underlying toxic effects. They found that exposure to heavy oils decreases pathogen resistance through negative regulation of genes related to the immune system. Rainbow trout (Oncorhynchus mykiss) larvae showed a constant toxicity when treated with heavy fuel oil stranded on gravel (allowing for a continual exposure of weathering oil) and were particularly sensitive to 3- and 4-ringed alkylated-PAHs (Martin et al., 2014). However, it remains unclear what other compounds could have explained a constant toxicity when most of the PAHs and alkylated-PAHs are known to degrade over time as the oil mixture weathered. Therefore, the purpose of this study was to mimic a crude oil spill in a 
freshwater lake to study its chemical weathering profile along with corresponding changes in fathead minnow (Pimephales promelas) embryotoxicity with time. This fish is native to freshwater lakes in North America from the Rocky Mountains in Canada southwards to Texas and northern Mexico (Danylchuk \& Paszkowski, 2012).

\section{Materials and methods}

\subsection{Chemicals and water source}

Mixed Sweet Blend (MSW; a conventional crude oil) was obtained directly from a pipeline in Edmonton, Alberta, Canada. North Saskatchewan River water (Alberta, Canada) was provided by the municipal water facility for Edmonton before the potable water treatment process was performed. River sediment was collected from a floodplain on the bank of the North Saskatchewan River. All other chemicals and solvents were purchased from Sigma Aldrich as "reagent grade" and were used as received.

\subsection{Sediment analyses}

Sediment was added to increase the sediment loading of the test water. It was homogenized prior to use and analysis. The particle size distribution of the sediment was determined by the following in-house procedure. Approximately 40 grams of material was added to a $400 \mathrm{~mL}$ beaker. The beaker was half filled with tap water and stirred on a hot plate at $400 \mathrm{rpm}$ and $60^{\circ} \mathrm{C}$ for 30 minutes. The beaker was then transferred to a sonic bath where it was sonicated for 30 minutes. A pre-weighed stack of sieves (no. 60, 100, 140, 200 and 325) was placed on a Ro-Tap and secured in place. The mesh in these sieves corresponds to $250 \mu \mathrm{m}, 150 \mu \mathrm{m}, 106 \mu \mathrm{m}, 75 \mu \mathrm{m}$ and 
$45 \mu \mathrm{m}$. Each sieve was wetted with tap water in turn to ensure that hydrostatic pressure was not a factor in the sieving. The sample was then transferred into the top most sieve quantitatively. A strike plate was placed on top and water inlets secured. The sample was agitated for 15 minutes on the Ro-tap while $8 \mathrm{~L}$ of tap water flowed through the sieves and was collected along with the fines in a 10L pail. After 15 minutes, each sieve was examined to see if any more material was forth coming. When all the sieves expelled clean water, the sieves were allowed to dry in an oven at $110^{\circ} \mathrm{C}$ for 16 hours. The pail with the fines was allowed to settle for 24 hours. After 16 hours, the sieves were weighed again to determine the amount of solids captured. After 24 hours, the water cap was removed from the fines pail and the fines were transferred to a preweighed $500 \mathrm{~mL}$ aluminium pan for drying in an oven. The next day, the fines were weighed, collected out of the pan, disaggregated, and homogenized before further analysis. A quantity of 5.5 grams was removed for sedigraph analysis. This material was put into a beaker along with $40 \mathrm{~mL}$ of $0.05 \%$ Calgon solution. The sample was then stirred on a hot plate at $400 \mathrm{rpm}$ and $60^{\circ} \mathrm{C}$ for 30 minutes. The beaker was then transferred to a sonic bath where it was sonicated for a further 30 minutes. Once homogenized, it was transferred to a plastic container quantitatively. Two drops of photo flow were added to the solution and it was agitated for one minute with a sonic probe. The sample was run using an autosampler and a 5120 Sedigraph III particle analyzer. The Sedigraph can determine percent passing between $55 \mu \mathrm{m}$ and $0.2 \mu \mathrm{m}$ (see S1).

\subsection{Water Analyses}

This article is protected by copyright. All rights reserved. 
The following water analyses were performed. Inorganic anions were measured by ion chromatography according to EPA Method 300.0 (Pfaff, 1993). A five point calibration curve was generated for each analyte of interest and validated with two different quality control/quality assurance samples. Sample alkalinity was measured with a PC-titrate supplied by Mantech Associates. The water sample was titrated with 0.02N hydrochloric acid until the $\mathrm{pH}$ of the sample reached 4.5. The endpoint was determined using a pH electrode. A standardization protocol was followed for determining the concentration of the titration acid and buffer solutions were used as calibration standards. Quality control samples with known concentrations of bicarbonate and carbonate were inserted into the sample sequence to ensure that the instrument was operating correctly. The conductivity of each sample was measured with a handheld Exstix conductivity total dissolved solids (TDS) meter. The meter was calibrated daily with three calibration standards: $84 \mu \mathrm{S}, 1413 \mu \mathrm{S}$, and 12,880 $\mu \mathrm{S}$. Samples and standard solutions were allowed to reach room temperature before measurements were taken. Samples were analyzed for cations in solution according to EPA Method 6010B. Analysis was completed using an Agilent 8800 Inductively Coupled Plasma Tandem Mass Spectrometer (ICP MS/MS). Four-point calibration curves were used for the analysis and calibration standards were made from certified stock solutions. The matrix for the aqueous introduction was a 5\% nitric acid solution. Samples were not diluted or digested for the analysis.

Contents of different types of organic compounds in the contaminated water were measured. Benzene-toluene-ethylbenzene-xylene (BTEX) contents in the sampled waters were measured using EPA 5021/8015\&8260 GC-MS \& FID. Total

This article is protected by copyright. All rights reserved. 
concentrations of polycyclic aromatic hydrocarbons (PAHs) and alkylated PAHs in selected water samples were analyzed using EPA 3510C/8270-GC/MS. Total organic carbon (TOC) of water samples collected during the test was determined using a Shimadzu TOC V CPH instrument according to a modified version of American Standards for Testing and Materials (ASTM) D7573-09 (2009).

In addition to the above analyses of organic compounds in undiluted contaminated water samples, the diluted contaminated water samples used for toxicity tests were also analyzed at each time point for PAHs and alkylated PAHs, volatile organic compounds (VOCs), and for molecular profiling of oxidized compounds. For PAH analyses, approximately $800 \mathrm{~mL}$ of $\mathrm{pH} 2$ acidified water sample was extracted by liquid-liquid extraction using dichloromethane (DCM) to a final volume of $100 \mathrm{~mL}$ of DCM. A 10-mL aliquot of this extract was solvent-exchanged to hexane, treated with silica gel and concentrated down to $1 \mathrm{~mL}$. The prepared sample was analyzed without further purification using GC/MSD (Agilent Technologies 7890B GC and 5977A MSD) for nine classes of PAHs, totaling 126 alkylated PAHs (CEAEQ 2016) and the VOCs (CEAEQ 2015). The same extract used for alkylated PAHs/VOC analysis was also used for the molecular profiling of unidentified oxidized compounds by GC/QTOF (Agilent Technologies 7890B GC and 7200B QTOF mass spectrometer).

\subsection{Preparation of hydrocarbon-contaminated water in the spill test tank}

The spill tank measuring 3 m x 1 m x 1.5 m ( $\mathrm{L} \mathrm{x} \mathrm{W} \mathrm{x} \mathrm{H)} \mathrm{and} \mathrm{made} \mathrm{of} \mathrm{316-}$ stainless steel, is shown in Fig. S1-a. To start the tank test, approximately 1,200 L of fresh river water was added in the tank to a height of $0.7 \mathrm{~m}$. One end of the tank was built at an incline to simulate a shoreline situation. The tank had a paddle-style wave-

This article is protected by copyright. All rights reserved. 
generating flap to create waves during the test where a motor setting of $105 \mathrm{rpm}$ generated breaking waves with a wavelength of $60 \mathrm{~cm}$, a wave amplitude of approximately $8 \mathrm{~cm}$, and a wave period of $0.5 \mathrm{~s}$. Three temperature transmitters (TT1001, TT-1002, and TT-1003) were located at different heights to provide a temperature profile in the tank. TT-1001 was above the water surface and recorded the ambient air temperature throughout the test period, while TT-1002 and TT-1003 recorded the water temperature. For this test, an external heater unit was used to maintain the water temperature at $15^{\circ} \mathrm{C} \pm 1^{\circ} \mathrm{C}$ using heat-exchange coils located along the bottom and sides of the spill tank; the ambient air temperature an average of $14^{\circ} \mathrm{C}$ $\pm 2^{\circ} \mathrm{C}$. No light source was available to simulate the effects of photo-oxidation. The intrinsically safe LED-based lights installed were chosen to meet the electrical code for the potentially explosive environment above the tank. As LED lights tend to have low or no emissions in the ultraviolet wavelength range (Cosmin and Paul, 2015), it was expected that photo-oxidation contributions to weathering processes in this tank system were also low.

At the start of the test, $2.4 \mathrm{~kg}$ of North Saskatchewan River sediment was added to the water and mixed with waves for 5 min to achieve a content of 2,000 ppm of suspended sediment. Immediately afterwards, $8.255 \mathrm{~kg}$ of fresh MSW (approximately $10 \mathrm{~L}$ ) was poured onto the surface of the water through a pouring device attached to the edge of the tank (Fig. S2-b), and time was recorded as the zero hour (T0). The pouring device was designed to direct the oil out sideways to prevent oil splashing down into the water column. Waves were applied continuously for the first 2 days then turned off for the next two days, where the on-off cycle was repeated 
over the duration of the test. When the change over from off to on, or on to off occurred on a weekend, the state was maintained until the Monday for a third day in the state. Over the entire 28-day period, the waves were on half the time to promote surface mixing, and off half the time to promote biodegradation activities, if existed. The evaporation of water during the test was made up using reverse osmosis water to maintain a constant water height of $70 \mathrm{~cm}$.

Water samples were removed at intervals during the 28 days from the tank sample port, labelled with a red " $\mathrm{X}$ " in Fig. S1-a for analyses and toxicity testing. At the end of the test, weathered oil samples from different locations in the tank were

recovered for mass balance purposes and analyses. Finally, the majority of the sediment was collected from the bottom of the tank. The oil content of the sediment was determined by the in-house extraction method described in the sediment analyses section. Pictures were taken to document the tank contents at the various sampling time points (Fig. S2). For toxicity testing five 20-L pails of water were collected in amber glass bottles on each of the sample days (day 1 , day 6 , day 14 , day 21 , and day 28) and shipped overnight to the Institut national de la recherche scientifique (INRS), Quebec City, QC, Canada for embryotoxicity testing.

\subsection{Physical and chemical analyses of the oil}

Fresh MSW was tested as it was received. At the end of the test (day 28), after collecting the required water samples for analyses, weathered oils from the water surface (floating oil) and shoreline (shoreline oil) were recovered and weighed. Both fresh and weathered oils were analyzed using the following methods. Density was measured using a densitometer at 20,25 and $30^{\circ} \mathrm{C}$ as per ASTM method D4052 
(2016). Density at $15^{\circ} \mathrm{C}$ was calculated from the linear relationship between the measured densities and temperature. Viscosity was measured using a Brookfield viscometer at 20,25 and $30^{\circ} \mathrm{C}$ as per ASTM method D7042 (2016). Kinematic viscosity at $15^{\circ} \mathrm{C}$ was estimated from the logarithmic relationship between the experimentally determined kinematic viscosities and the inverse of the absolute temperature $\left(\mathrm{K}^{-1}\right)$. In both cases, the $\mathrm{R}^{2}$ values of MSW data were close to $100 \%$ for the three measured values. The $\mathrm{R}^{2}$ values for the slick oil data were lower (> $94 \%$ ) due to the heterogeneity of the water present in the floating oil emulsions.

The boiling point distributions of fresh MSW and the weathered oils by high temperature simulated distillation (HTSD) were determined using method (ASTM D7169, 2016) on an Agilent gas chromatograph with Analytical Control software. As well, both fresh MSW and floating oil were distilled to a cut point of $204^{\circ} \mathrm{C}$ to separate the light oil fraction [initial boiling point to $204^{\circ} \mathrm{C}\left(\mathrm{IBP}-204^{\circ} \mathrm{C}\right)$ ] from the heavier portion of the oil $\left(\mathrm{BP}>204^{\circ} \mathrm{C}\right)$ using ASTM D1160 (2015). The basic sediment and water content (BS\&W) was measured using ASTM D7829 (2018) to quantify water in the fresh MSW and weathered shoreline oil. For the weathered slick oil, water content was measured by freezing the water in its $\mathrm{IBP}-204^{\circ} \mathrm{C}$ fraction and then pouring the little oil present off the ice and recording their weights. The $1 \mathrm{wt} \%$ oil recovered in the IBP $-204^{\circ} \mathrm{C}$ fraction was found to actually be $\mathrm{BP}>204^{\circ} \mathrm{C}$ material removed by the imprecision of the distillation method.

Elemental analysis was performed to determine the contents of carbon (C), hydrogen $(\mathrm{H})$, nitrogen $(\mathrm{N})$, and sulfur (S) using an Elementar Analyzer (ASTM D5291, 2016). Oxygen (O) content was determined with an Elementar Oxygen 
Analyzer using an in-house modified ASTM method. Reported elemental data were normalized with respect to total CHNSO content. Separations of the fresh and weathered oil samples into saturates, aromatics, resins, and asphaltenes (SARA) subfractions were performed according to an in-house modification of ASTM methods D2007 (2019) and D2549 (2017).

\subsection{Embryotoxicity assays}

Fathead minnow (FHM; Pimephales promelas) eggs were collected from the colony held at INRS. Eggs were obtained following an established breeding protocol based on the INRS Animal Care Committee and the Canadian Council for Animal Care guidelines. Eggs were collected from approximately 30 couples of FHM, and randomized before use. For each of the time points of interest (day 1, day 6, day 14, day 21, and day 28), MSW-contaminated water stock was stored at $4^{\circ} \mathrm{C}$. For each assay, dilutions were prepared for the following nominal dilutions $12.5,25,50$, and $100 \% \mathrm{v} / \mathrm{v}$ from the MSW-contaminated water stock. The fractions were diluted with North Saskatchewan River water and the experimental design included a river water control ( $0 \%$ oil). A second control was included to ensure that the river water did not affect the tests. It was a reconstituted water control prepared according to a standard protocol (ASTM International, 2004; per liter of deionized water: $0.55 \mathrm{mg} \mathrm{NaBr}, 51.2$ mg $\mathrm{NaHCO}_{3}, 2.1 \mathrm{mg} \mathrm{KCl}, 35.3 \mathrm{mg} \mathrm{CaCl}$, $3.4 \mathrm{mg} \mathrm{CaSO} \cdot 2 \mathrm{H}_{2} \mathrm{O}$, and $32.8 \mathrm{mg} \mathrm{MgSO}_{4}$ at $\mathrm{pH}$ 7.6-7.9). The dilution fractions were made in 1-L glass jars and $150 \mathrm{~mL}$ of the dilutions were divided equally into $250 \mathrm{~mL}$ glass jars each containing 25 embryos, with five replicates for each concentration and control. Dilutions were prepared fresh daily. The embryos were exposed from the fertilized egg stage (stage 1) to hatching 
time (stage 32; approx. 5 days). All animal work was conducted in accordance with the INRS Animal Care Committee and the Canadian Council for Animal Care guidelines.

For each bioassay, jars were checked daily for mortality at the time of static daily renewal. Dead embryos were recorded and removed to prevent the spread of pathogens. When all of the embryos hatched, the exposure was completed. Embryos were randomly selected from the five replicate jars for either malformation or gene expression analysis. For malformation analysis, embryos were analyzed individually (40 embryos per treatment). For gene expression analysis, embryos were collected by pools of 6 for 6 replicates $(n=36)$ and flash frozen in liquid nitrogen before storing at $-80^{\circ} \mathrm{C}$ before further analysis. Malformation analysis and embryo full body length measurement were performed using a Nikon SMZ18 stereomicroscope (Nikon Canada, Mississauga, ON). Embryos were analyzed and scored for presence of malformations of the heart tube, craniofacial, spinal deformity, pericardial, and yolk sac edema. Embryos were considered "malformed" if they exhibited at least one malformation.

\subsection{Gene expression analysis}

RNA was isolated from embryo tissue $(n=6)$ using the RNeasy Micro kit (Qiagen) following the manufacturer's protocol. The purity and concentration of isolated RNA was assessed using a spectrophotometer (Nanodrop-2000, Fisher Scientific, Ottawa, ON). QuantiTect Reverse Transcription Kit (Qiagen) was used to convert the RNA to complementary DNA (cDNA) with $1 \mu \mathrm{g}$ RNA input and random primers. A no-reverse transcriptase (NoRT) control was also prepared. Each cDNA 
sample was diluted to 1:40 and 1:80 for optimized quantitative polymerase chain reaction (qPCR) analysis.

Relative mRNA levels of target genes were assessed using a CFX96 Touch Real-Day PCR Detection System (Bio-Rad Laboratories Inc., Mississauga, Ontario) following MIQE guidelines (Bustin, et al., 2009). GoTaq qPCR Mastermix (Promega, Madison, WI, USA) containing Taq polymerase, nucleotides, double-stranded binding fluorescent dye, $\mathrm{MgCl}_{2}$, and reaction buffer was mixed with the appropriate forward and reverse primers for each target gene (Table S5). A standard curve was prepared in duplicate on each plate with serial-diluted pooled cDNA to create a calibration curve with a dilution factor of four (0.0048-

50 ng). Each plate contained a no-template control to ensure nuclease-free water was not contaminated with DNA and a no reverse transcriptase control to ensure RNA samples were not contaminated with DNA. Each sample was run in duplicate, with six to eight replicates per treatment that were divided evenly across four plates per target gene. The thermocycler profile consisted of 35 cycles of heating and cooling: $95{ }^{\circ} \mathrm{C}$ to activate Taq polymerize and denature cDNA strands, and a gene-dependent optimized temperature for primer annealing and elongation $58{ }^{\circ} \mathrm{C}$. Standard curve efficiencies of 90.0-111.5\%, and $\mathrm{R}^{2}$ values of 0.978-0.999 were considered optimized. Gene expression analysis was performed for two normalizing genes (ribosomal protein L8 (rpl8) and elongation factor 1 alpha (ef1a)). Target genes cytochrome p450-1a; (cyp1a) and glutathione transferase (gst), known to be highly responsive to oil exposure, were chosen as biomarkers of exposure (Alsaadi et al. 2018). Target genes 
were normalized to the average transcript level of rpl8 and ef1a to determine the relative fold change (all the primer information can be found in Table S1).

\subsection{Statistical analyses}

Normalized fold change values were considered outliers if they were 1.5 time outside of the interquartile range and removed from the analysis. All statistical analyses were performed in Prism (v.7, GraphPad). Transcript levels were transformed to respect the assumptions of normality (Shapiro-Wilk normality test) and equal variances (Brown-Forsythe test). One-way ANOVA was used to determine significant difference between standard deviations of treatments. If significant, Tukey's honest significance test was used for post-hoc analysis. Two-way ANOVA was used to determine significant differences in mortality and malformation for each treatment. Regression analysis was performed when there were five or more data points to analyze. Linear regression was performed to determine the median lethal concentration (LC50) from the total polycyclic aromatic hydrocarbon (TPAH) concentration range plotted on a $\log _{10} \mathrm{X}$-axis.

\section{Results}

\subsection{Preparation of hydrocarbon contaminated water in the Spill Tank}

River water was analyzed before and after the 28-day spill test and selected results for $\mathrm{pH}$, conductivity, and total dissolved solid (TDS) are shown in Table S2. After adding sediment to the river water, a slight increase of water $\mathrm{pH}$ was observed, while the addition of oil had a negligible effect on $\mathrm{pH}(\mathrm{T} 0)$. The water $\mathrm{pH}$ decreased slightly by the end of the test. The conductivity was not affected by either the addition of sediment or oil, but also dropped slightly by the end of the spill test. TDS values did

This article is protected by copyright. All rights reserved. 
not change significantly from start to the end of the test. The selected major cations and anions shown in Table S3 indicated slightly decrease of both cations and anions in the start and the end, except for sodium content. The size distribution and composition of the sediment added to the tank are shown in Fig. S3 and Table S4, respectively.

\subsection{Oil Behavior - Mass Balance Determination}

To understand the behavior of the oil in the fresh water, it was important to determine the mass balance (by weight) distribution of the original fresh oil into weathered oil as floating oil and oil deposited on the shoreline, as well as lost to the air, aqueous phase and sediment. The masses of floating and shoreline oil were determined by the masses of oil recovered after correction for water trapped in the oil as emulsions. The water contents of the recovered oils compared to the fresh oil are shown in Table 1. The slick oil was highly emulsified containing 73 wt\% water; the shoreline oil had lower water content with $16 \mathrm{wt} \%$. Table 1 also gives the contents of oil fractions that boil below $204^{\circ} \mathrm{C}$ (initial boiling point [IBP] to $204^{\circ} \mathrm{C}$ ) and above $204^{\circ} \mathrm{C}\left(\mathrm{BP}>204^{\circ} \mathrm{C}\right)$.

To quantify the loss of light ends of the oil to the air by evaporation and biodegradation, the boiling point distributions of the recovered oils were compared to that of the fresh oil (Fig. 1). The initial boiling points (IBPs) of the weathered oils were close to $230^{\circ} \mathrm{C}$ compared to the fresh oil that had an IBP below the detection limit for the analyses $\left(36^{\circ} \mathrm{C}\right)$. Consequently, over the 28-day test, close to $42 \mathrm{wt} \%$ of the fresh crude was lost from the oil phase. As these low-boiling, organic compounds are smaller than 15 carbons in size, it is assumed that they were lost from the oil phase

This article is protected by copyright. All rights reserved. 
to either the air or water due to a combination of evaporation and oxidation/dissolution processes to either carbon dioxide or water-soluble compounds in the water column.

Over the 28-day spill test, it was observed that the tank water color changed with time where day 1 had the blackest water column compared to that observed on days $6,14,21$, and 28 . This visual evidence of oil in the aqueous phase as either oil droplets or dissolved organic compounds correlated well with organic chemical analysis results shown in Figs. 2 to 4, where the highest BTEX, TOC, and PAH contents in the aqueous phase were found on the first day. This likely resulted from the highly-fluid (low viscosity) oil being mixed into the water with the wave action on day 1 while by day 6, the weathered oil was less fluid (higher viscosity) and so resisted mixing by the waves and so remained on the surface. The BTEX content diminished to close to the detection limit after about $24 \mathrm{~h}$ (Fig. 2). The total PAHs and alkylatedPAHs measured in the water column decreased rapidly over the first few hours as well, and remained relatively constant and low after the day 6 time point (120 h) (Fig. 3). The concentration of TOC in the aqueous phase (Fig. 4) also shows an initial decrease until day 5 (96 h). Interestingly, in contrast to the BTEX and PAH results, after day 5 the TOC values increased steadily until the end of the test. The trend of increasing TOC values does not agree with BTEX and PAH contents but correlates well with the increasing contents of oxidized organic species found in the water column during the later time period shown in Fig 5.

After the floating oil and shoreline oil samples were removed from the tank, the slurry of bottom sediment and water was collected. The average oil content in the mixture was $138 \pm 57 \mathrm{~g} / \mathrm{kg}$ sediment, accounting for approximately $10.4 \mathrm{wt} \%$ of the 
spilled oil. By difference, the remaining $3.4 \mathrm{wt} \%$ of oil was lost in the water column as dissolved or dispersed oil. The chart showing the distribution of oil between the different environmental phases is shown in Fig. 6.

\subsection{Oil Behaviour - Properties and Composition Changes}

The fresh MSW is a conventional crude with a medium density of 0.8233 $\mathrm{g} / \mathrm{mL}$, and a relatively low viscosity of $5.9 \mathrm{cSt}$ at the water temperature of $15^{\circ} \mathrm{C}$ (Table 2). After weathering for 28 days in the spill tank, Table 2 also shows that the density and viscosity of the slick oil emulsion had increased to $0.9286 \mathrm{~g} / \mathrm{mL}$ and $1.14 \times 10^{5} \mathrm{cSt}$ at $15^{\circ} \mathrm{C}$, respectively. Although the density of the floating oil confirms that it is expected to float, efficient recovery of the oil with its $73 \mathrm{wt} \%$ water content would be hampered by its high viscosity and increased volume.

The $\mathrm{BP}>204^{\circ} \mathrm{C}$ fractions of the fresh crude and floating oil described in Table 1 were subjected to further compositional analyses. Both were separated into subfractions based on polarity resulting in their contents of saturates, aromatics, resins and asphaltenes. As well, the elemental (CHNSO) analyses of the $\mathrm{BP}>204^{\circ} \mathrm{C}$ fractions were determined. Both sets of results are shown in Table 3. Saturates content in the $\mathrm{BP}>204^{\circ} \mathrm{C}$ fraction of the fresh oil was significantly higher than that of the weathered oil. The loss of saturates in the weathered oil appears to be countered by similar increases in the contents of all three polar sub-fractions. The elemental contents data support the SARA results in that the hydrogen to carbon ratio of the fresh $\mathrm{BP}>204^{\circ} \mathrm{C}$ fraction at 1.79 is higher than that of the weathered product at 1.76, suggesting higher aromatic carbon content. The $\mathrm{BP}>204^{\circ} \mathrm{C}$ fraction from the floating oil also contained higher nitrogen and oxygen contents that contributed to its higher polarity. The

This article is protected by copyright. All rights reserved. 
increased oxygen content in the oil would be due to the same oxidation activities that resulted in the increasing contents of oxidized organic compounds with time in the water column, shown in Fig. 5.

\subsection{Morphological and physiological effects in fish}

There were no significant differences in mortalities, hatching time, or larvae weight compared with contaminated water treatments over time (Figs. S4-S6). For the malformations shown in Fig. 7, the occurrence of malformed embryo initially reflected TPAH concentrations, then at later times increased with time despite low TPAH concentrations. Data were clustered into two groups. In the first cluster, day 1 and day 6 induced malformations at higher TPAH concentrations than in the second cluster (day 14, day 21, and day 28). These data suggest that the contaminated water samples generated from day 14 to day 28 were more toxic than those generated earlier. The most common malformations observed included pericardial edema, followed by heart tube, spinal and craniofacial deformities, and yolk sac edema (Table S5).

\subsection{Gene expression analysis}

Following the results of malformations (i.e., two clusters, see Section 3.3), gene expression analysis was performed on the most toxic-related cluster (day 14 to day 28) in order to determine if the animals were differentially coping with the range of concentrations of MSW contaminated water. Transcript levels of cyp1a significantly differed between negative control and the low $(p=0.023)$, medium $(p<0.0001)$, and high $(p<0.0001)$ MSW contaminated water treatments (Fig. 8). Levels of cyp1a transcripts increased with TPAH concentrations in a curvilinear manner. Regression analysis was performed, and cyp1a transcript level increased in a concentration- 
dependent manner. A similar profile was observed for gst in which day 14 was the only time point exhibiting a concentration response.

\section{Discussion}

Increased knowledge of the fate and behavior of oil after a spill in water is needed to help responders make decisions on how to mitigate the potential environmental damage from oil spills. An intrinsically-safe oil spill test facility has been constructed at the Natural Resources Canada laboratory in Devon, Alberta that is large enough to be able to weather oil in the presence of waves but small enough that water and sediment samples collected contain detectable quantities of contaminating organic compounds. During spill tank tests, the composition of the organic compounds originating from the crude oil changes with time due to weathering processes such as dispersion, evaporation, dissolution, emulsion formation, and oxidation. Little photooxidation is expected during weathering in this system due to the lighting LED sources used. Biodegradation is likely to have happened due to the usage of natural North Saskatchewan river water and sediment in the test, which contain natural microbial consortia. Given that this is a stagnant system, the concentrations of contaminants are high relative to any large-volume or flowing-water environment. However, by being able to measure the evolution of types of contaminants present with time, and carrying out serial dilutions to determine concentration dependencies of the toxic effects detected, insight is gained as to how toxicity in low-flow and smaller-volume environments that can include oil trapped in sediment may evolve with time.

For this work, a spill test was conducted in the tank for 28 days to simulate an accidental release of MSW crude oil into a subarctic freshwater lake or river during

This article is protected by copyright. All rights reserved. 
late summer-type conditions (an average water temperature of $15^{\circ} \mathrm{C}$ and an average air temperature of $14{ }^{\circ} \mathrm{C}$ ). Analyses of the organic composition of the water, weathered oil, and sediment collected at the end of the test, together with water analyses and fish toxicity testing throughout the test period, has provided detailed information about the fate and behaviour of compounds within the spilled oil over a given time.

In terms of oil spill behaviour, MSW crude is a conventional crude oil and so, having a medium density of $0.8233 \mathrm{~g} / \mathrm{mL}$ at the temperature of the water, may be expected to "float" and allow high recovery. However, the high fluidity (i.e., low viscosity; Table 2) of the fresh oil allowed the breaking waves employed to mix the oil into the water as small droplets. As sediment had just been added to the water, this facilitated sedimentation of oil droplets, resulting in $10.4 \mathrm{wt} \%$ of the oil being caught in the sunken sediment at the end of the test. As well, evaporation, and possibly biodegradation processes started soon after the oil was spilled. By the end of the 28day test, $42.0 \mathrm{wt} \%$ of the fresh oil had evaporated or was oxidized so that the initial boiling point of the floating recovered oil had increased to $230^{\circ} \mathrm{C}$. Most of the recovered oil was floating $(0.9286 \mathrm{~g} / \mathrm{mL}$ density; Table 2$)$ but was highly emulsified, containing $73 \mathrm{wt} \%$ water (Table 1 ) and was a relatively viscous material at $15^{\circ} \mathrm{C}$ (114,000 cSt; Table 2); a smaller portion of recovered oil adhered to the shoreline section of the tank. Together, the oil mass distribution of the fresh oil into weathered oil in the different environmental compartments after 28 days is shown in Fig. 6. This figure demonstrates that the maximum recovery from the water surface and shoreline that could have been achieved for this oil from a spill site would have been $44.2 \mathrm{wt} \%$. However, its high viscosity and water content would make recovery difficult. As well, 
even though the oil mat was still floating at the end of the test, $13.8 \mathrm{wt} \%$ was still lost to the water and sediment.

With regards to ecotoxicity, the impacts of oil contaminants upon biota in aqueous environments depends not only on the toxicity of the organic compound, but also on its aqueous solubility to become bioavailable. Analyses of both the recovered oil, and oxygenated organic compounds isolated from the water column, confirm that the oil was becoming oxidized with time. Biodegradation of the oil at the oil-water interface resulted in oxidized oil products, some of which were water-soluble and dissolved in the aqueous phase.

This study aimed to examine how oil weathering processes may affect the dissolved hydrocarbon profiles and their toxicity to fish over time. Figs. 2-4 show that the oil concentration in water was highest at T0 due to the initial dispersion of the fresh oil. The monoaromatics (measured as BTEX) have the highest water solubility in petroleum and their concentrations in water were also the highest at T0 (Fig. 2). Consequently, BTEX compounds would have contributed significantly to the total organic carbon (TOC) measured in the water over the first $24 \mathrm{~h}$ (Fig 4). Apart from BTEX, some short-chain alkanes, and small PAHs (e.g., naphthalene) or polar compounds may have contributed to the TOC in water (Lee et al., 2015). While dissolution of volatile saturates and aromatics is a competitive process with evaporation immediately after a spill, the quick decrease of BTEX in the water column over the first $24 \mathrm{~h}$ (day 2) to below detection limits also resulted in the significant decrease of TOC in the aqueous phase. For TPAH concentrations, since most of the PAHs and alkylated PAHs analyzed have very low water solubility and high boiling 
points $\left(>218^{\circ} \mathrm{C}\right)$, the high total $\mathrm{PAH}$ and alkylated $\mathrm{PAH}$ concentrations measured at T0 in Fig. 3 indicate that oil droplets were also present in the water column. The rapid reduction of TPAH concentrations after the first $3 \mathrm{~h}$ demonstrated that the oil droplets were relatively quick to either resurface or be pushed to the bottom by sedimentation processes. The fluctuation between $3 \mathrm{~h}$ and $24 \mathrm{~h}$ reflected certain small PAHs (e.g., naphthalene) taking time to partition into water. The continuous decrease of TOC concentration in water through this time period was consistent with the decrease of TPAH concentrations between $24 \mathrm{~h}$ (day 2) and $120 \mathrm{~h}$ (day 6), suggesting their removal by evaporation of smaller polyaromatic compounds (e.g., naphthalene), and oxidation processes.

Beyond 120 h (day 6), the values of the BTEX and TPAH concentrations were low for the remainder of the test period. This was expected, particularly for the BTEX concentrations. Fig. 5 suggests that the increasing TOC values reflect increasing concentrations of oxidized organic compounds. A major source of oxidized organic compounds in the aqueous phase would be from incomplete biodegradation of the oil where partially degraded, oxidized products would accumulate with time. Oxidized organic compounds will have increased water solubility compared to their solubility before the addition of oxygen. For instance, oxidized PAHs (like, ketone- or quinonesubstituted) partition better into the aqueous phase, showing an increase in water solubility and a decrease in lipophilicity (Idowu et al., 2019).

In terms of ecotoxicity, the increased water solubility or organic species by oxidation would increase the bioavailability of toxic compounds. However, the decrease in lipophilicity would be expected to decrease the uptake of the compounds This article is protected by copyright. All rights reserved. 
by biota. In this study, the oxidized compounds were determined to be more toxic than the identified PAHs and alkylated PAHs (Fig. 7). The malformation patterns matched the oxidized organic compound profile, where the fish embryos had higher proportions of malformations at lower TPAH concentrations from day 14 to day 28. These data suggest that the increased occurrence of fish malformations at the later times resulted from the increasing concentration of the unidentified oxidized compounds as the oil weathered. Several studies have reported increases in malformations with PAH concentrations on fish embryos (e.g., Carls et al. 2008; Dubansky et al. 2013; Incardona et al. 2014, Incardona et al. 2013; Mager et al. 2014), but few have studied the embryotoxicity of weathered oil, which would be a more realistic indicator of the potential impact of spilled oil on aquatic ecosystems. The weathered oil is a complex mixture that changes with time and environmental conditions (Hodson, 2017). Hansen and colleagues (2018) evaluated the toxicity of weathered crude oil (from 0 to 21 days) in a marine environment for Atlantic cod (Gadus morhua) and concluded that the metabolites produced from biodegradation, called the "unresolved complex mixture" fraction, were equally as toxic as the parent compounds. Robidoux et al. (2018) compared fathead minnow toxicity of weathered oil and fresh oil in minnows for seven days and observed that lethality was higher for fresh oil than for weathered oil, presumably due to the higher BTEX content in the fresh oil. Based on the present study, a proportion of the resulting "unresolved complex mixture" fraction would be the presence of unidentified oxidized compounds (Fig. 5). Few studies have addressed the toxicity of oxidized PAHs (or oxy-PAHs) to aquatic species. In zebrafish (Danio rerio) embryos, exposure to $0.1-2 \mu \mathrm{M}$ oxy-PAHs during early development yielded higher DNA damage than for embryos exposed to $1 \mu \mathrm{M}$ benzo[a]pyrene (McCarrick et

This article is protected by copyright. All rights reserved. 
al., 2019). Knecht and colleagues (2013) observed similar physiological and molecular effects to those reported in the present study (e.g., yolk sac edema, spinal curvatures, and change in the expression of genes related to oxidative stress) in zebrafish embryos exposed to 38 oxy-PAHs.

Although the last three time points (day 14 to day 28) yielded similar malformation patterns and TPAH concentrations, the increase in cyp1a mRNA levels was different among the time points. The induction of cyp1a is well known to be responsive to several PAHs (reviewed in Wallace et al. 2020); however, only the fraction at day 14 exhibited an increase in cyp1a mRNA levels. The lack of inductions observed at times day 21 and day 28 could be explained by an absence of aryl hydrocarbon receptor (AhR) agonists (e.g., 4-ring PAHs; Incardona et al., 2006), the presence of inhibitors, or the general disruption to the integrity of membranes, proteins and/or nucleic acids (narcosis). For example, in an exposure of 4,340 - 12,200 ng/L PAHs through oil gravel effluent for 48 h (day 3), olive flounder (Paralichthys olivaceus) embryos accumulated high PAH concentrations, but had a low cyp1a mRNA level-response (Jung et al., 2015). It was noteworthy that the reduction of cyp1a expression increased the prevalence of pericardial edema and poor cardiac looping in zebrafish embryos compared to normal embryos exposed to 9 ppb PAHs. This suggests that cyp1a induction protects the embryo (Hicken et al., 2011). However, despite lacking a cyp1a response, other effects could occur in the fish embryos through AHR-independent pathways (Incardona et al., 2005). Similarly, the mRNA profile of gst also involved in the detoxification pathway was only significantly expressed at day 14 . Together, these data highlight the importance to

This article is protected by copyright. All rights reserved. 
continue studying side-by-side the chemistry and toxicity profiles of oil complex mixtures as they weather.

In conclusion, in the course of the 28-day spill test, the highest concentrations of total PAHs and alkylated PAHs in the water column were observed immediately after the oil was added to the tank. These concentrations decreased to $500 \mu \mathrm{g} / \mathrm{L}$ at 120 h (day 6), and then to less than $200 \mu \mathrm{g} / \mathrm{L}$ at the end of the spill test. The BTEX concentrations in the water column were all below the detection limit after $24 \mathrm{~h}$ (day 2). The TOC concentrations in the water column showed a continuous decrease from the first hour until 120 h (day 6) due to the loss of water-soluble volatile compounds, and a subsequent increase apparently due to increasing concentrations of oxidized organic compounds accumulating in the water at later time points. This study suggests that hydrocarbon contaminated water from day 14 to day 28 are the most toxic fractions to the fish embryos, which corresponded to increasing concentrations of unidentified oxidized compounds. This study highlights a novel area for oil research, which could help to better understand the toxicity associated with oil weathering for aquatic species.

Supplemental Data-The Supplemental Data are available on the Wiley Online Library at DOI: 10.1002/etc.xxxx.

Acknowledgment - This project was funded by the Government of Canada's Oceans Protection Plan Program (Natural Resources Canada), Canada’s Research Chair Program (to VSL; \#950-230442), and the CONACYT-México (to LRLJ). Part of the analyses was funded by a program of the Quebec Government, the Stratégie maritime 
du Gouvernement du Québec, Plan d’action 2015-2020. The authors would like to acknowledge that ALS Global performed the BTEX and PAH analyses of the undiluted water samples, and would like to thank Hena Farooqi leading the tank test operations. Analyses conducted at CanmetENERGY were performed by both the Standard Analytical Laboratory, and Upstream and Environment Team in Devon.

Disclaimer - The authors have no conflict of interest to declare.

Data availability statement-Data, associated metadata, and calculation tools are available from the corresponding author (valerie.langlois@inrs.ca).

\section{References}

Adams, E.E., Socolofsky, S.A., Boufadel, M., 2013. Comment on "Evolution of the Macondo Well Blowout: simulating the effects of the circulation and synthetic dispersants on the subsea oil transport”. Environ Sci Technol. 47, 11905.

Adams, J., Sweezey, M., and Hodson, P. V. 2014. Oil and oil dispersant do not cause synergistic toxicity to fish embryos. Environ Toxicol Chem. 33:107-114.

Alsaadi, F., Madison, B.N., Brown, R.S., Hodson, P.V., Langlois, V.S. 2018. Morphological and molecular effects of two diluted bitumens on developing fathead minnow (Pimephales promelas) Aq Tox. 204:107-116.

ASTM D1160-15, Standard Test Method for Distillation of Petroleum Products at Reduced Pressure, ASTM International, West Conshohocken, PA, 2015.

ASTM E1706-04, Test Method for Measuring the Toxicity of Sediment-Associated Contaminants with Freshwater Invertebrates, ASTM International, West Conshohocken, PA, 2004.

This article is protected by copyright. All rights reserved. 
ASTM D2007-19, Standard Test Method for Characteristic Groups in Rubber Extender and Processing Oils and Other Petroleum-Derived Oils by the ClayGel Absorption Chromatographic Method, ASTM International, West Conshohocken, PA, 2019.

ASTM D2549-02(2017), Standard Test Method for Separation of Representative Aromatics and Nonaromatics Fractions of High-Boiling Oils by Elution Chromatography, ASTM International, West Conshohocken, PA, 2017.

ASTM D4052-16, Standard Test Method for Density, Relative Density, and API Gravity of Liquids by Digital Density Meter, ASTM International, West Conshohocken, PA, 2016.

ASTM D5291-16, Standard Test Methods for Instrumental Determination of Carbon, Hydrogen, and Nitrogen in Petroleum Products and Lubricants, ASTM International, West Conshohocken, PA, 2016.

ASTM D7042-16, Standard Test Method for Dynamic Viscosity and Density of Liquids by Stabinger Viscometer (and the Calculation of Kinematic Viscosity), ASTM International, West Conshohocken, PA, 2016.

ASTM D7169-16, Standard Test Method for Boiling Point Distribution of Samples with Residues Such as Crude Oils and Atmospheric and Vacuum Residues by High Temperature Gas Chromatography, ASTM International, West Conshohocken, PA, 2016.

ASTM D7573-09, Standard Test Method for Total Carbon and Organic Carbon in Water by High Temperature Catalytic Combustion and Infrared Detection, ASTM International, West Conshohocken, PA, 2009.

This article is protected by copyright. All rights reserved. 
ASTM D7829-13(2018), Standard Guide for Sediment and Water Determination in Crude Oil, ASTM International, West Conshohocken, PA, 2018.

Beyer, J., Trannum, H.C., Bakke, T., Hodson, P.V., Collier, T.K. 2016. Environmental effects of the Deepwater Horizon oil spill: A review. Mar Pollut Bull. 110(1):28-51.

Bornstein, J.M., Adams, J.E., Hollebone, B., King, T., Hodson, P.V., and Brown, R.S. 2014. Effects-driven chemical fractionation of heavy fuel oil to isolate compounds toxic to trout embryos. Environ Toxicol Chem 33: 814-824.

Brown ED, Baker TT, Hose JE, Kocan RM, Marty GD, McGurk MD, Norcross BL, Short J. 1996. Injury to the early life history of Pacific herring in Prince William Sound after the Exxon Valdez oil spill. Am Fish Soc Symp 18:448462.

Bustin, S.A., Benes, V.B., Garson, J.A., Hellemans, J., Huggett, J., Kubista, M., Mueller, R., Nola, T., Pfaffl, M.W., Shipley, G.L., Vandesompele, J., Wittwer, C.T. 2009. The MIQE guidelines: Minimum information for the publication of quantitative real-Day PCR experiments. Clin Chem 55: 611-622.

Carls, M. G., Holland, L., Larsen, M., Collier, T. K., Scholz, N. L., \& Incardona, J. P. 2008. Fish embryos are damaged by dissolved PACs, not oil particles. Aq Tox. 88: 121-127.

Carls, M.G., Rice, S.D., and Hose, J.E. 1999. Sensitivity of fish embryos to weathered crude oil: Part I. low level exposure during incubation causes malformations,

This article is protected by copyright. All rights reserved. 
genetic damage, and mortality in larval Pacific herring (Clupea pallasi). Environ Toxicol Chem. 18: 481-493.

CEAEQ 2015. Détermination des composés organiques volatils dans l'eau et les sols: dosage par « Purge and Trap » couplé à un chromatographe en phase gazeuse et à un spectromètre de masse. MA. 400-COV 2.0. http://www.ceaeq.gouv.qc.ca/methodes/pdf/MA400COV20.pdf

CEPA 2016. CEPA announces 2016 pipeline industry performance report. Retrieved from https://cepa.com/en/2016/06/cepa-announces-2016-pipeline-industryperformance-report/ on Sept. $18^{\text {th }}, 2018$.

Cherr, G. N., Fairbairn, E., \& Whitehead, A. (2017). Impacts of petroleum-derived pollutants on fish development. Annual review of animal biosciences, 5, 185203.

Crosby, S., Fay, R., Groark, C., Kani, A., Smith, J., and Sullivan, T.Transporting Alberta's Oil Sands products: Defining the issues and assessing the risks. U.S. Dept. of Commerce, NOAA Technical Memorandum NOS OR\&R 44: 1-153

Datta, S., Hansen, L., McConnell, L., Baker, J., LeNoir, J., \& Seiber, J. N. (1998). Pesticides and PCB contaminants in fish and tadpoles from the Kaweah River Basin, California. Bull Environ Contam Toxicol. 60: 829-836.

Danylchuk Tonn WM; Paszkowski CA, 2012. Fishes of Wisconsin. Wisconsin, USA: Wisconsin Department of Natural Resources, US Geological Survey. http://www.fow-ebook.us

This article is protected by copyright. All rights reserved. 
Davidson, C., and Knapp, R. A. 2007. Multiple stressors and amphibian declines: dual impacts of pesticides and fish on yellow-legged frogs. Ecol Appl. 17: 587-597.

Denny, J. S. (1988). Guidelines for the culture of fathead minnows, Pimephales Promelas for use in toxicity tests. Duluth, MN: US Environmental Protection Agency, Environmental Research Laboratory.

Dew, W.A., Hontela, A., Rood, S.B., Pyle, G.G. 2015. Biological effects and toxicity of diluted bitumen and its constituents in freshwater systems. J Appl Toxicol. 35: $1219-1227$

CEAEQ 2016. Détermination des hydrocarbures aromatiques polycycliques: dosage par chromatographie en phase gazeuse couplée à un spectromètre de masse. MA. 400-HAP 1.1. http://www.ceaeq.gouv.qc.ca/methodes/pdf/MA400HAP11.pdf

Cosmin, T. and Paul, L. (2015). A summary of LED lighting impacts on health, International Journal of Sustainable Lighting. 1: 3-4.

Dubansky, B., Whitehead, A., Miller, J.T., Rice, C.D., Galvez, F., 2013. Multitissue molecular, genomic, and developmental effects of the Deepwater Horizon oil spill on resident Gulf killifish (Fundulus grandis). Environ Sci Technol. 47, 5074-5082.

Dupuis, A., \& Ucán-Marín, F. (2015). A literature review on the aquatic toxicology of petroleum oil: An overview of oil properties and effects to aquatic biota. Canadian Science Advisory Secretariat.

Eriyamremu, G. E., Osagie, V. E., Omoregie, S. E., and Omofoma, C. O. 2008. Alterations in glutathione reductase, superoxide dismutase, and lipid 
peroxidation of tadpoles (Xenopus laevis) exposed to Bonny Light crude oil and its fractions. Ecotoxicol Environm Saf. 71: 284-290.

Fallahtafti, S., Rantanen, T., Brown, R. S., Snieckus, V., and Hodson, P. V. 2011. Toxicity of hydroxylated alkyl-phenanthrenes to the early life stages of Japanese medaka (Oryzias latipes). Aq Tox. 106-107: 56-64.

Fanali, L.Z., Franco-Belussi, L., Bonini-Domingos, C.R., de Oliveira, C. 2018. Effects of benzo[a]pyrene on the blood and liver of Physalaemus cuvieri and Leptodactylus fuscus (Anura: Leptodactylidae). Environm Poll. 237: 93-102.

Fernandez, M., l'Haridon, J. 1994. Effects of light on the cytotoxicity and genotoxicity of benzo(a)pyrene and an oil refinery effluent in the newt. Environ Mol Mutag. 24(2):124-36.

GOC [Government of Canada] 2013. Properties, composition and marine spill behaviour, fate and transport of two diluted bitumen products from the Canadian oil sands. Federal Government Technical Report.

Gosselin, P. et al. 2010. The Royal Society of Canada Expert Panel: Environmental and Health Impacts of Canada’s Oil Sands Industry.

Government of CanadaHansen, B. H., Farkas, J., Nordtug, T., Altin, D., \& Brakstad, O. G. 2018. Does microbial biodegradation of water-soluble components of oil reduce the toxicity to early life stages of fish? Environ Sci Technol. 52(7), 4358-4366.

Heintz, R.A., Short, J.W., and Rice, S.D. 1999. Sensitivity of fish embryos to weathered crude oil: Part II. Increased mortality of pink salmon (Oncorhynchus gorbuscha) embryos incubating downstream from weathered Exxon Valdez crude oil. Environ. Toxicol. Chem. 18: 494-503.

This article is protected by copyright. All rights reserved. 
Hicken, C.E., Linbo, T.L., Baldwin, D.H., Willis, M.L., Myers, M.S., Holland, L., Larsen, M., Stekoll, M.S., Rice, S.D., Collier, T.K., Scholz, N.L., Incardona, J.P. 2011. Sublethal exposure to crude oil during embryonic development alters cardiac morphology and reduces aerobic capacity in adult fish. Proc Natl Acad Sci. 108(17):7086-90.

Hodson, P.V., Wallace, S.J., de Solla, S.R., Head, J., Hepditch, S.L.J., Parrott, J.L., Thomas, P.J., Berthiaume, A., Langlois, V.S. Polycyclic aromatic compounds (PACs) in Canada: The challenges of ecological risk assessments. Environ Poll. Under review.

Hodson, P.V. 2017. The toxicity to fish embryos of PAH in crude and refined oils. Arch Environ Contam Toxicol. 73: 12-18.

Hof, C., Araújo, M. B., Jetz, W., and Rahbek, C. 2011. Additive threats from pathogens, climate and land-use change for global amphibian diversity. Nature, 480: 516-519.

Idowu, O., Semple, K.T., Ramadass, K., O'Connor, W., Hansbro, P., Thavamani, P. 2019. Beyond the obvious: Environmental health implications of polar polycyclic aromatic hydrocarbons. Environ Int. 123:543-557.

Incardona, J. P., Carls, M. G., Teraoka, H., Sloan, C. A., Collier, T. K., and Scholz, N. L. 2005. Aryl hydrocarbon receptor-independent toxicity of weathered crude oil during fish development. Environ Health Perspect. 113:1755-1762.

Incardona, J.P., Day, H.L., Collier, T.K., Scholz, N.L., 2009. Cardiac arrhythmia is the primary response of embryonic Pacific herring (Clupea pallasi) exposed to crude oil during weathering. Environ Sci Technol. 1;43(1):201-7.

This article is protected by copyright. All rights reserved. 
Incardona, J.P., Day, H.L., Collier, T.K., Scholz, N.L. 2006. Developmental toxicity of 4-ring polycyclic aromatic hydrocarbons in zebrafish is differentially dependent on $\mathrm{AH}$ receptor isoforms and hepatic cytochrome P4501A metabolism. Toxicol. Appl. Pharmacol. 217 (3), 308-321.

Incardona, J.P., Gardner, L.D., Linbo, T.L., Brown, T.L., Esbaugh, A.J., Mager, E.M., Stieglitz, J.D., French, B.L., Labenia, J.S., Laetz, C.A., Tagal, M., Sloan, C.A., Elizur, A., Benetti, D.D., Grosell, M., Block, B.A., Scholz, N.A., 2014. Deepwater Horizon crude oil impacts the developing hearts of large predatory pelagic fish. Proc. Natl. Acad. Sci. U. S. A. 111, E1510-E1518.

Incardona, J.P., Swarts, T.L., Edmunds, R.C., Linbo, T.L., Aquilina-Beck, A., Sloan, C.A., Gardner, L.D., Block, B.A., and Scholz, N.L. 2013. Exxon Valdez to Deepwater Horizon: Comparable toxicity of both crude oils to fish early life stages. Aqua. Toxicol. 142: 303-316

Jung, J.H., Kim, M., Yim, U.H., Ha, S.Y., Shim, W.J., Chae, Y.S., Kim, H., Incardona, J.P., Linbo, T.L., Kwon, J.H. 2015. Differential toxicokinetics determines the sensitivity of two marine embryonic fish exposed to Iranian heavy crude oil. Environ Sci Technol. 49(22):13639-48.

Jung, Y., Ahn, Y.G., Kim, H.K., Moon, B.C., Lee, A.Y., Hwang, G.-S., 2011. Characterization of dandelion species using 1H NMR-and GC-MS-based metabolite profiling. Analyst 136, 4222-4231

Knecht, A.L., Goodale, B.C., Truong, L., Simonich, M.T., Swanson, A.J., Matzke, M.M., et al. 2013. Comparative developmental toxicity of environmentally relevant oxygenated PAHs. Toxicol App Pharmacol. 271, 266-275.

This article is protected by copyright. All rights reserved. 
Lee, J.W., Won, E.-J., Raisuddin, S., Lee, J.-S., 2015. Significance of adverse outcome pathways in biomarker-based environmental risk assessment in aquatic organisms. J Environ Sci. 35, 115-127.

Lee, K., Boufadel, M., Chen, B., Foght, J., Hodson, P., Swanson, S., Venosa, A. 2015. Expert Panel report on the behaviour and environmental impacts of crude oil released into aqueous environments. Royal Society of Canada 2015.

Mager, E.M., Esbaugh, A.J., Stieglitz, J.D., Hoenig, R., Bodinier, C., Incardona, J.P., Scholz, N.L., Benetti, D.D., Grosell, M., 2014. Acute embryonic or juvenile exposure to Deepwater Horizon crude oil impairs the swimming performance of mahi-mahi (Coryphaena hippurus). Environ Sci Technol. 48, 7053-7061.

Martin, J. D., Adams, J., Hollebone, B., King, T., Brown, R. S., and Hodson, P. V. 2014. Chronic toxicity of heavy fuel oils to fish embryos using multiple exposure scenarios. Environ Toxicol Chem. 33: 677-687.

McCarrick, S., Cunha, V., Zapletal, O., Vondráček, J., Dreij, K. 2019. In vitro and in vivo genotoxicity of oxygenated polycyclic aromatic hydrocarbons. Environ Poll. 246, 678-687.

Meador, J. P., \& Nahrgang, J. (2019). Characterizing crude oil toxicity to early-life stage fish based on a complex mixture: are we making unsupported assumptions. Environmental science \& technology, 53(19), 11080-11092.

Nakayama, K., Kitamura, S.-I., Murakami, Y., Song, J.-Y., Jung, S.-J., Oh, M.-J., and Iwata, H. 2008. Toxicogenomic analysis of immune system-related genes in Japanese flounder (Paralichthys olivaceus) exposed to heavy oil. Mar Poll Bull. 57: 445-452.

This article is protected by copyright. All rights reserved. 
Pfaff, J. D. (1993). Method 300.0 Determination of inorganic anions by ion chromatography. US Environmental Protection Agency, Office of Research and Development, Environmental Monitoring Systems Laboratory, 28.

Robidoux, P. Y., Virginie, B., Judith, L., \& Marc, D. (2018). Assessment of acute and chronic toxicity of unweathered and weathered diluted bitumen to freshwater fish and invertebrates. Ecotoxicol Environm Saf. 164, 331-343.

Wallace, S.R., de Solla, S.R., Head, J., Hodson, P.V., Parrott J., Thomas, P., Langlois, V.S. 2020. Effects of polycyclic aromatic compounds in wildlife. Environ Poll. In press.

Wang, Z., Hollebone, B.P., Fingas, M., Fieldhouse, B., Sigouin, L., Landriault, M., Smith, P., Noonan, J., Thouin, G., Weaver, J.W., 2003. Characteristics of spilled oils, fuels, and petroleum products: 1. Composition and properties of selected oils. U.S. Environmental Protection Agency, Washington, DC.

Wang, Z., Fingas, M., Yang, C., Hollebone, B., Peng, X., 2004. Biomarker fingerprinting: application and limitation for correlation and source identification of oils and petroleum products. Proceedings of the $27^{\text {th }}$ Arctic and Marine Oilspill Program (AMOP) Technical Seminar. Environment Canada, Ottawa, ON, Canada, p. 103.

Wang, Z., Stout, S.A., Fingas, M., 2006. Forensic fingerprinting of biomarkers for oil spill characterization and source identification. Environ Forensic 7, 105-146.

This article is protected by copyright. All rights reserved. 
Wu, D., Wang, Z., Hollebone, B., McIntosh, S., King, T., \& Hodson, P. V. (2012).

Comparative toxicity of four chemically dispersed and undispersed crude oils to rainbow trout embryos. Environmental Toxicology and Chemistry, 31(4), 754-765.

Figure 1. Boiling point distributions of fresh MSW and its weathered oils (either floating or from shoreline) after 28 days (648 h).

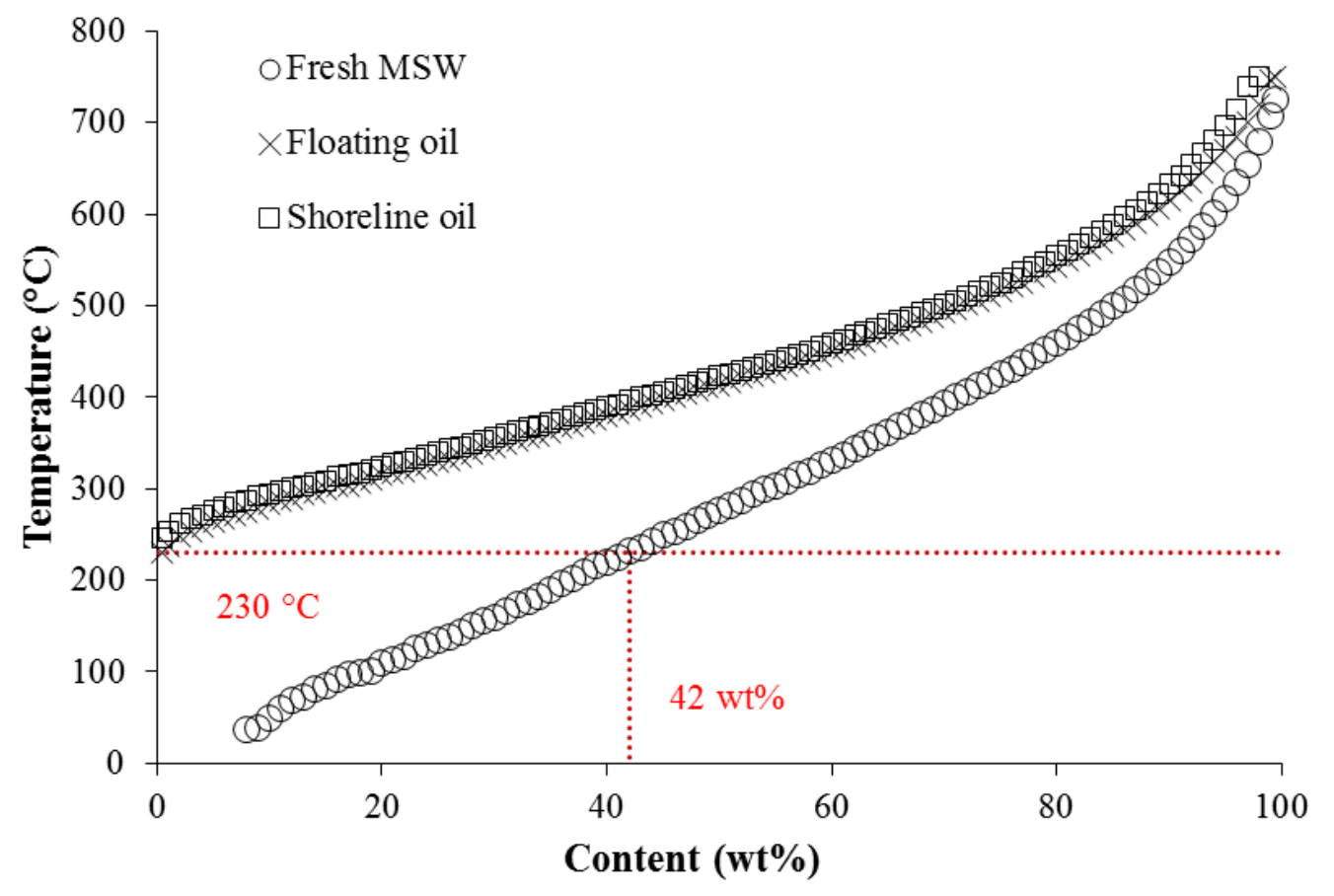

This article is protected by copyright. All rights reserved. 
Figure 2. BTEX concentration in water sampled at different times over $24 \mathrm{~h}$ (a) and 648 h (b).

a)
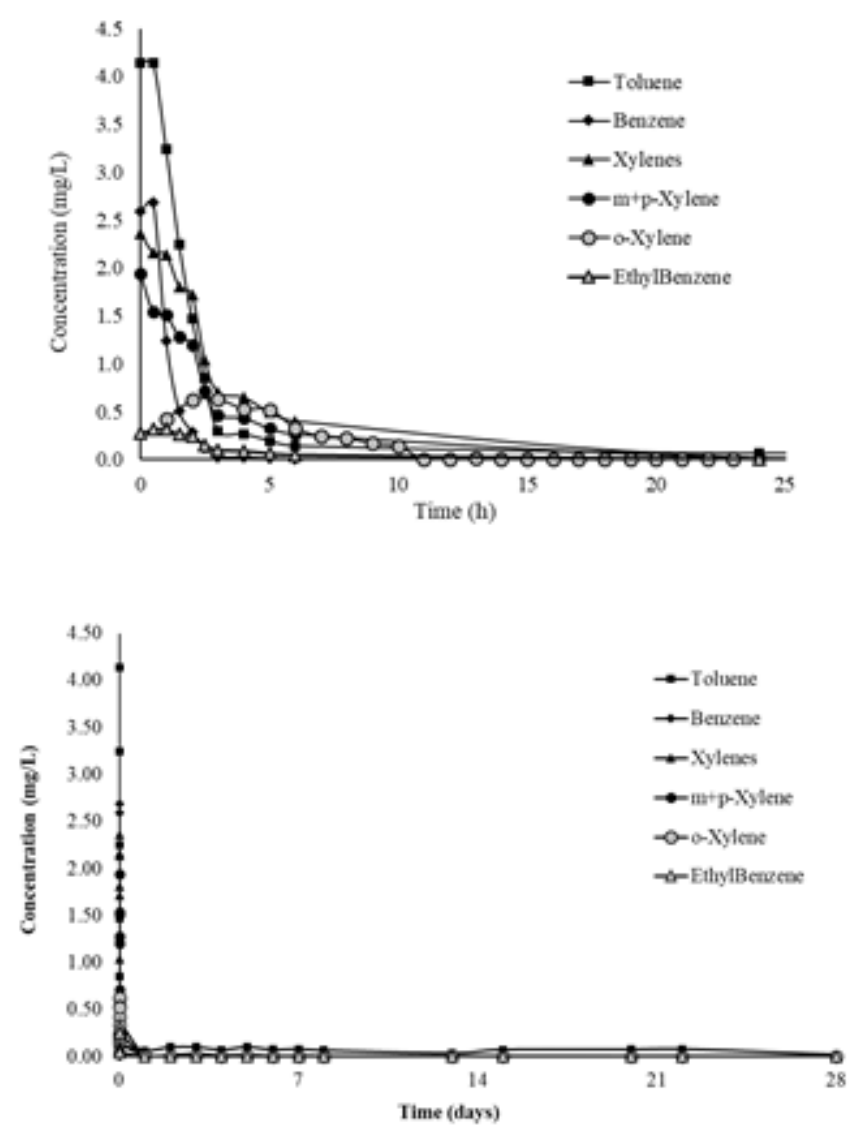

b)

This article is protected by copyright. All rights reserved. 
Figure 3. Total PAHs and alkylated-PAHs concentration in water at different time points over $648 \mathrm{~h}$.

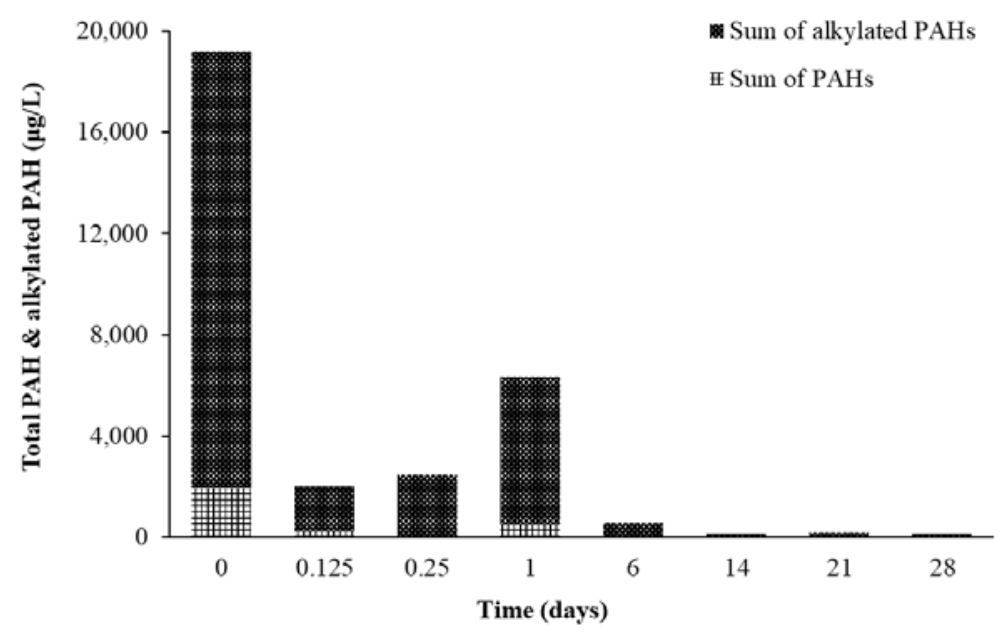

This article is protected by copyright. All rights reserved. 
Figure 4. Total organic carbon in water at different time points over 28 days (648 hours).

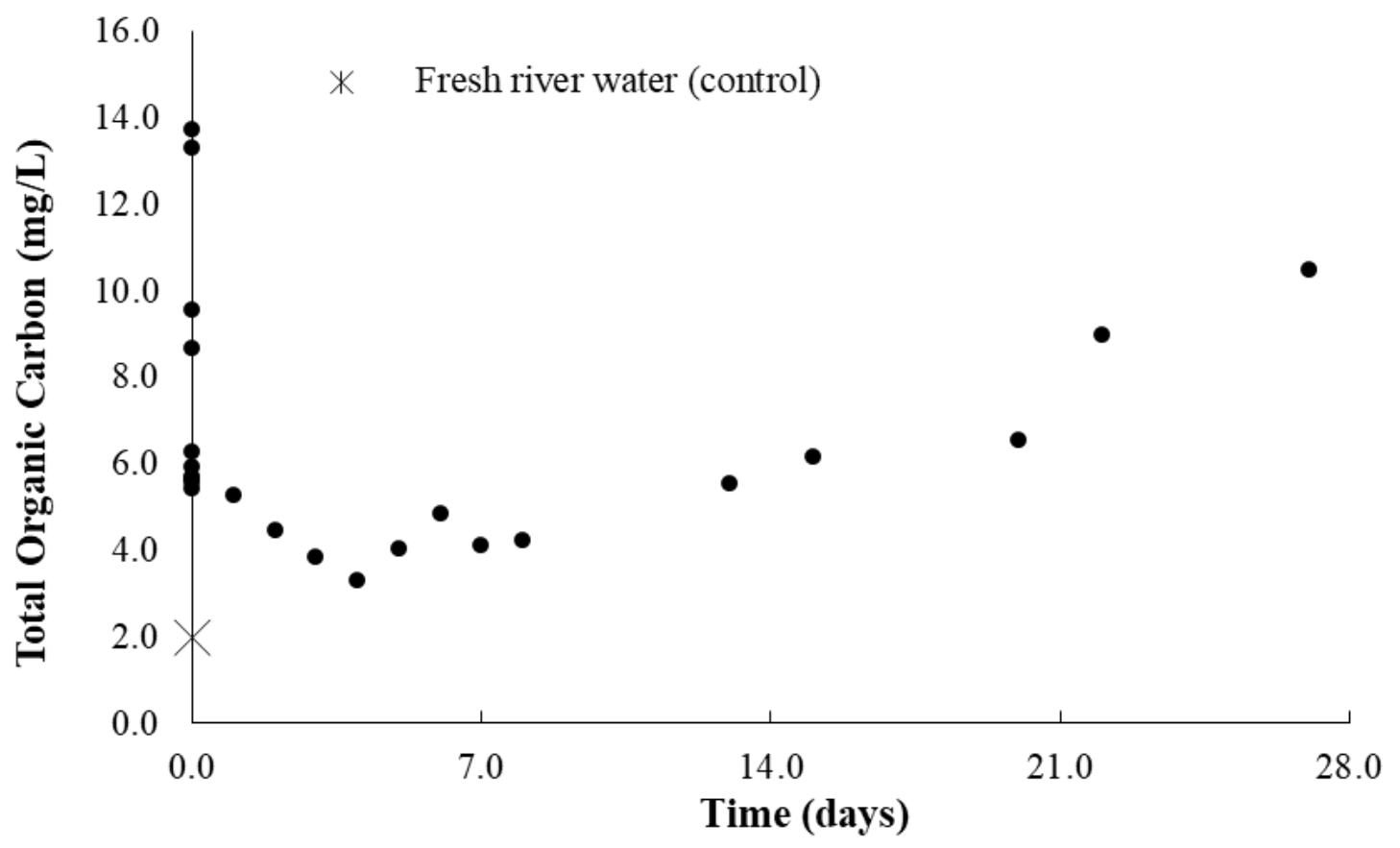

This article is protected by copyright. All rights reserved. 
Figure 5. Relative contents of possible oxidized organic compounds found in the contaminated water dilutions over time normalized against an internal standard (ISTD), Acenaphthene-D10. The y-axis is the ISTD area ratio (ISTD peak area / unidentified compound detected peak area).

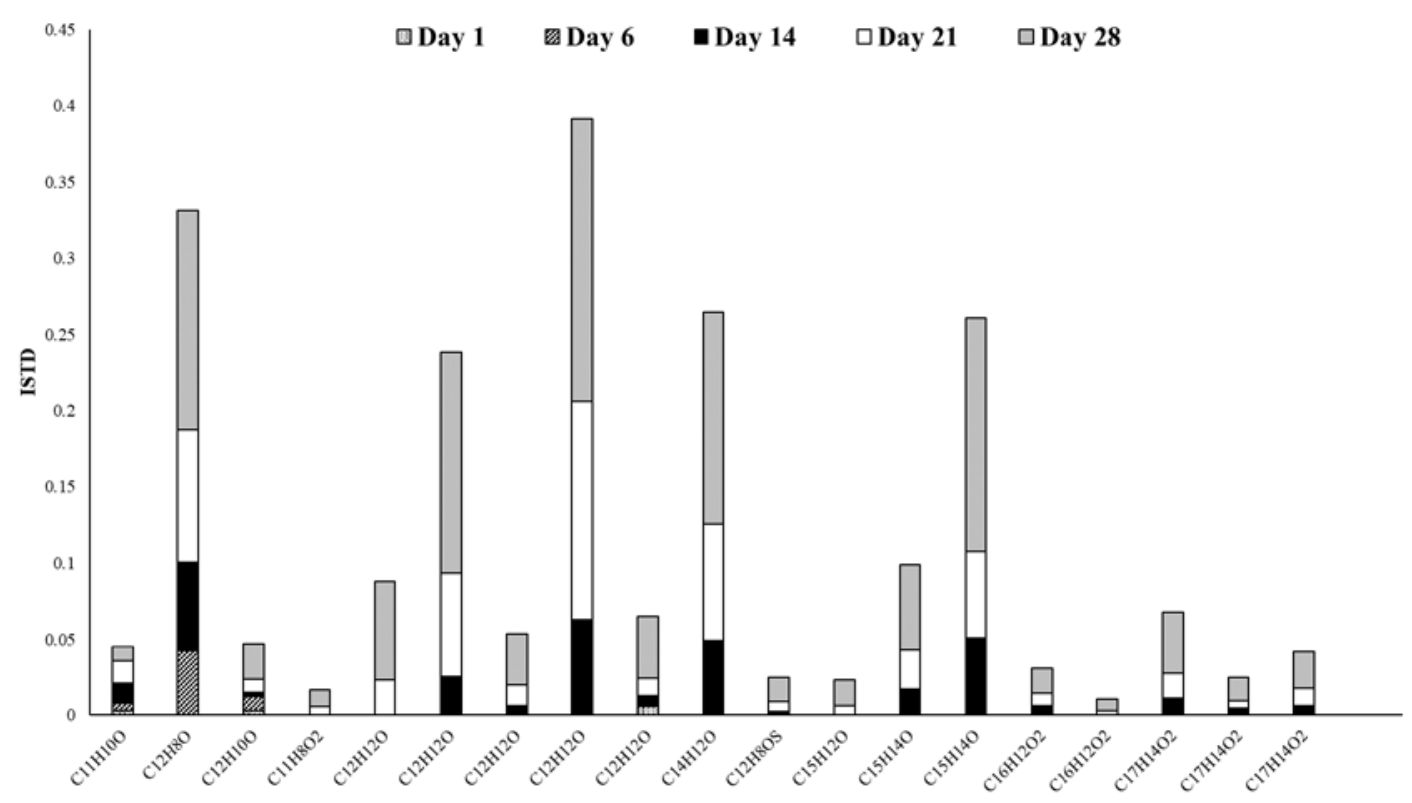

This article is protected by copyright. All rights reserved. 
Figure 6. Distribution of total oil mass (by weight \%) 28 days after the spill.

\section{Oil mass distribution}

- Oil lost to air

« Floating oil

๘ Shoreline oil

Oil in water column

Oil in bottom sediment

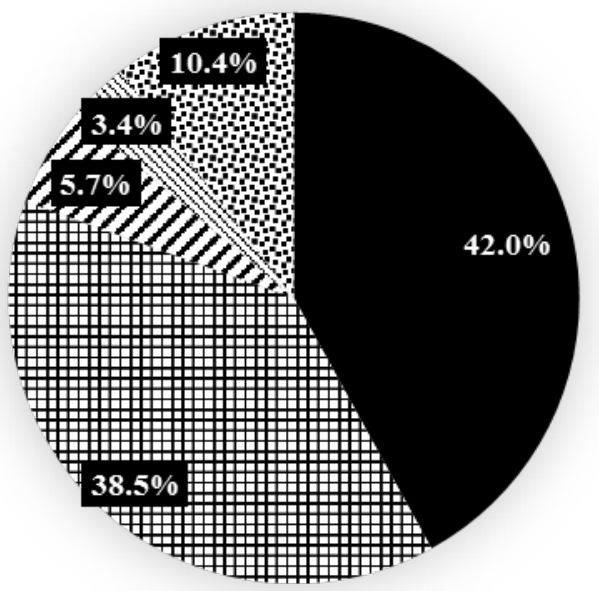

This article is protected by copyright. All rights reserved. 
Figure 7. Prevalence of malformations (\% malformed) in Pimephales promelas embryos after exposure to weathering oil water dilutions of mixed sweet blend (MSW). The independent axis represents the mean logarithmic total polycyclic aromatic hydrocarbons (TPAHs). Data clustered into two groups, cluster 1: day 1 \& day 6, compared to cluster 2: day 14 to 28.
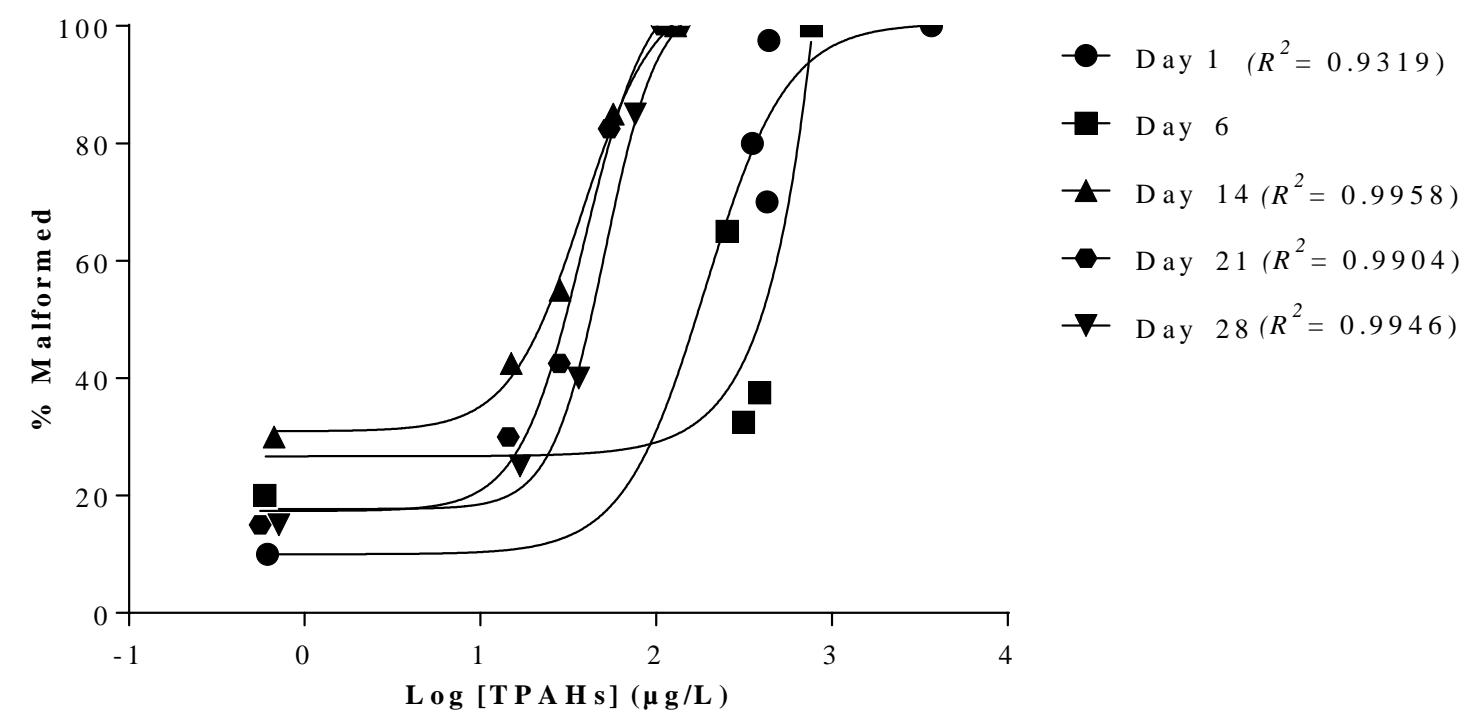

This article is protected by copyright. All rights reserved. 
Figure 8. Levels of cyp1a and gst transcripts in Pimephales promelas embryos exposed to varying concentrations of MSW contaminated water. a) The effects of contaminated water dilutions on cyp1a mRNA level at TPAH concentrations ranging between 0.1 and $10 \mu \mathrm{g} / \mathrm{L}$; b) Changes of gst transcripts are normalized to the mean of odc and rpl8 \pm SEM.

a)

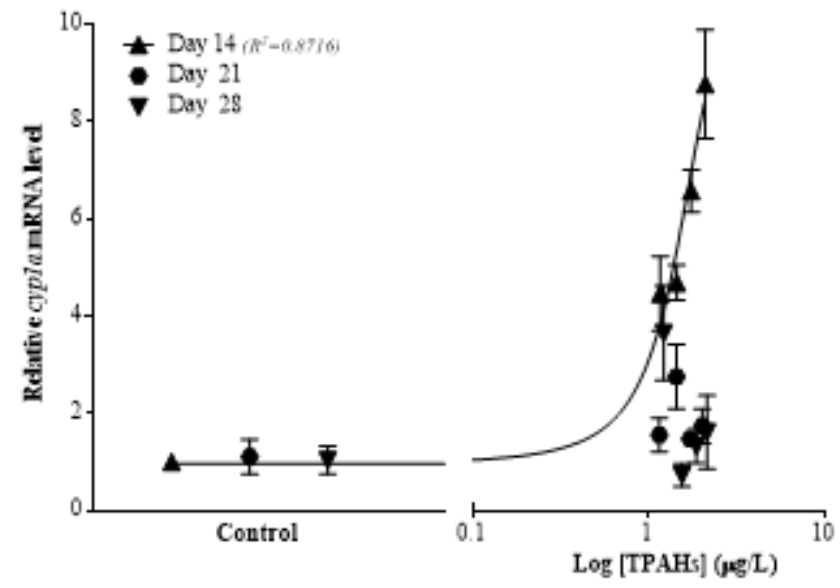

b)

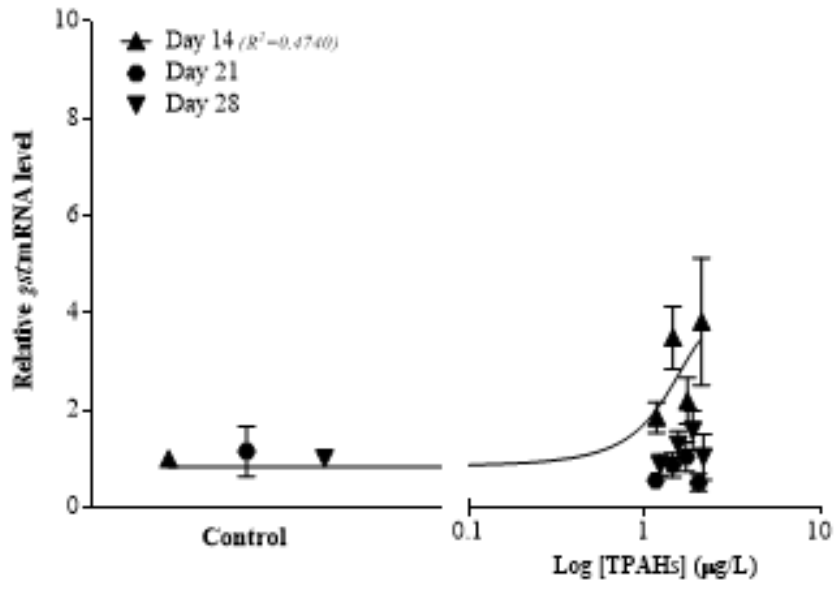

This article is protected by copyright. All rights reserved. 
Table 1. Contents of distillation fractions and water in fresh and recovered (floating and shoreline) oil.

\begin{tabular}{lccc}
\hline \multicolumn{1}{c}{ Fraction, wt $\%$} & Fresh MSW & Floating oil & Shoreline oil \\
\hline $\mathrm{IBP}-204^{\circ} \mathrm{C}$ & 37.4 & 0.0 & 0.0 \\
$\mathrm{BP}>204^{\circ} \mathrm{C}$ & 62.5 & 26.7 & 84.0 \\
& & & 16.0 \\
Water & 0.1 & 73.3 & \\
\hline
\end{tabular}

Table 2. Density and viscosity of fresh MSW and floating oil.

\begin{tabular}{ccc}
\hline Property & Fresh MSW & Floating oil \\
\hline Density, g/mL & & \\
at $15^{\circ} \mathrm{C} *$ & 0.8233 & 0.9286 \\
at $20^{\circ} \mathrm{C}$ & 0.8197 & 0.9269 \\
at $25^{\circ} \mathrm{C}$ & & \\
& 0.816 & 0.9245 \\
at $30^{\circ} \mathrm{C}$ & & 0.9234 \\
$\mathrm{R}^{2}$ & 0.8124 & 0.9560
\end{tabular}

Viscosity, cSt

This article is protected by copyright. All rights reserved. 


\begin{tabular}{lcc} 
at $15^{\circ} \mathrm{C} *$ & 5.9 & $1.14 \times 10^{5}$ \\
at $20^{\circ} \mathrm{C}$ & 4.7 & $2.28 \times 10^{4}$ \\
& 3.8 & $1.76 \times 10^{3}$ \\
at $25^{\circ} \mathrm{C}$ & 3.0 & 672 \\
at $30^{\circ} \mathrm{C}$ & & \\
$\mathrm{R}^{2}$ & 0.9984 & 0.9405 \\
\hline
\end{tabular}

* Calculated based on the measured data at 20,25 and $30^{\circ} \mathrm{C}$ as explained in the text.

Table 3. Contents of SARA subfractions and elements (CHNSO) in the $\mathrm{BP}>204^{\circ} \mathrm{C}$ boiling fractions of the fresh crude and weathered floating oil.

\begin{tabular}{lcc}
\hline Fraction, wt $\%$ & Fresh MSW & Floating oil \\
\hline SARA & 57.0 & \\
Saturates & 27.5 & 49.9 \\
Aromatics & 13.7 & 30.5 \\
Resins & & 16.4 \\
Asphaltenes & 1.8 & 3.2 \\
Elemental & & \\
Carbon & & \\
& & \\
& & \\
\end{tabular}

This article is protected by copyright. All rights reserved. 


\begin{tabular}{lcc} 
Hydrogen & 13.0 & 12.7 \\
Nitrogen & 0.03 & 0.14 \\
Sulfur & 0.7 & 0.6 \\
Oxygen & $<0.1$ & 0.2 \\
\hline
\end{tabular}

This article is protected by copyright. All rights reserved. 